\title{
Quality Comparison of Biosimilar and Copy Filgrastim Products with the Innovator Product
}

\author{
Liem Andhyk Halim ' Maripaz Márquez ${ }^{1,2}$ • Roel F. Maas-Bakker' • Gilberto Castañeda-Hernández ${ }^{2} \cdot$ Wim Jiskoot $^{3}$. \\ Huub Schellekens'
}

Received: 21 March 2018 / Accepted: 4 September 2018 / Published online: 2 October 2018

(C) The Author(s) 2018

\begin{abstract}
Purpose Filgrastim, a recombinant human granulocytecolony stimulating factor, is widely used to treat congenital and acquired neutropenia. Following patent expiration of the innovator filgrastim product, biosimilar filgrastim products have been approved in the EU and shown to be comparable with the innovator with respect to quality, safety and efficacy. In less regulated markets, copy filgrastim products are available but data about their quality are scarce. In the present study, we provide a head-to-head comparative study on the quality of biosimilar and copy filgrastim products. Methods Innovator filgrastim product, Neupogen ${ }^{\circledR}$, two EU-licensed biosimilars, Zarzio ${ }^{\circledR}$ and Tevagrastim ${ }^{\circledR}$, and two copy filgrastim products, Biocilin ${ }^{\circledR}$ and PDgrastim ${ }^{\circledR}$, were subjected to peptide mapping, circular dichroism spectroscopy, fluorescence spectroscopy, sodium dodecyl sulfate polyacrylamide gel electrophoresis, high performance size-exclusion chromatography, reversed-phase ultra-performance liquid chromatography, endotoxin test, flow imaging microscopy and in vitro potency assay.
\end{abstract}

Results Zarzio ${ }^{\circledR}$ and Tevagrastim ${ }^{\circledR}$ have comparable quality to Neupogen ${ }^{\circledR}$, while Biocilin ${ }^{\circledR}$ showed a

Liem Andhyk Halim and Maripaz Márquez contributed equally to this work.

Huub Schellekens
h.schellekens@uu.nl

Department of Pharmaceutics, Utrecht Institute for Pharmaceutical Sciences (UIPS), Utrecht University, Universiteitsweg 99, Room 3.76, 3584, CG Utrecht, The Netherlands

2 Departamento de Farmacología, Centro de Investigación y de Estudios Avanzados del Instituto Politécnico Nacional (Cinvestav), Av. IPN 2508, Col. San Pedro Zacatenco, C.P, 07360 Ciudad de México, Mexico

3 Division of BioTherapeutics, Leiden Academic Centre for Drug Research, Leiden University, P.O. Box 9502, 2300, RA Leiden, The Netherlands significantly lower and PDgrastim ${ }^{\circledR}$ a higher specific activity. Moreover, PDgrastim ${ }^{\circledR}$ showed a higher level of impurities and a lower thermo stability than the other products.

Conclusions Except for the deviating specific activities of the two copy filgrastim products, we found no substantial differences in product quality between the filgrastim products studied.

KEY WORDS biosimilar · copy product · filgrastim · protein characterization · quality

\begin{tabular}{|c|c|}
\hline \multicolumn{2}{|c|}{ ABBREVIATIONS } \\
\hline AIDS & Acquired Immunodeficiency Syndrome \\
\hline $\mathrm{BPCl}$ Act & Biologics Price Competition and Innovation \\
\hline CD & Circular Dichroism \\
\hline CRS & Chemical Reference Substances \\
\hline E. coli & Escherichia coli \\
\hline EDQM & $\begin{array}{l}\text { European Directorate for the Quality of } \\
\text { Medicines and HealthCare }\end{array}$ \\
\hline EU & European Union \\
\hline FDA & Food and Drug Administration \\
\hline FWHM & Full Width at Half Maximum \\
\hline HP-SEC & $\begin{array}{l}\text { High Performance Size-Exclusion } \\
\text { Chromatography }\end{array}$ \\
\hline LAL & Limulus Amebocyte Lysate \\
\hline $\mathrm{MFI}$ & MicroFlow Imaging \\
\hline PEG & Polyethylene Glycol \\
\hline PFS & Pre-Filled Syringe \\
\hline Ph. Eur. & European Pharmacopeia \\
\hline PS80 & Polysorbate 80 \\
\hline rhG-CSF & $\begin{array}{l}\text { Recombinant Human Granulocyte-Colony } \\
\text { Stimulation Factor }\end{array}$ \\
\hline RP-UPLC & $\begin{array}{l}\text { Reversed Phase Ultra-Performance } \\
\text { Liquid Chromatography }\end{array}$ \\
\hline SDSPAGE & $\begin{array}{l}\text { Sodium Dodecyl Sulfate Polyacrylamide Gel } \\
\text { Electrophoresis }\end{array}$ \\
\hline
\end{tabular}


UMCU University Medical Centre Utrecht

US

United States

\section{INTRODUCTION}

Recombinant human granulocyte-colony stimulation factor (rhG-CSF) is one of the first recombinant biologics that was authorized for the use in hematology (1). Two different forms of rhG-CSF are distinguished, namely filgrastim (from Escherichia coli [E. coli], under the trade name Neupogen () and lenograstim (from Chinese hamster ovary cell, brand name Granocyte $\left.{ }^{\circledR}\right)(2)$. Filgrastim contains 175 amino acids and differs from the endogenous protein, as it lacks O-glycosylation and has an additional methionine group at the N-terminus (3). Its use was approved in 1991 in the EU and US. A next generation filgrastim is pegfilgrastim (brand name Neulasta ${ }^{\circledR}$ ). Owing to the covalent attachment of $20 \mathrm{kDa}$ polyethylene glycol (PEG) to the N-terminal methionyl residue of filgrastim, pegfilgrastim has extended circulating half-life, and thus can be administered less frequently than filgrastim (4).

RhG-CSF is commonly prescribed to treat both congenital and acquired neutropenia, such as in patients undergoing chemotherapy or patients diagnosed with advanced AIDS (5-7). Neutropenia is characterized by a low neutrophil count making patients more prone to bacterial infections. In addition, rhG-CSF is usually administered to donors of peripheral blood stem cells and progenitor cells prior to harvesting (8).

Patent expiration of innovator biologic products has created the possibility for companies to develop biosimilars. Within the EU, according to the European Medicines Agency (EMA), biosimilars are authorized via an abbreviated regulatory pathway, which requires demonstration of similarity in terms of quality, safety and efficacy, to an innovator product already licensed in the EU (9). Many countries are introducing specific biosimilar regulations using the European approach as guidance, but adapted to local needs and demands (10). In the US, the Biologics Price Competition and Innovation of 2009 (BPCI Act) enabled an abbreviated regulatory pathway for biosimilars. The Food and Drug Administration (FDA) issued a series of (draft) guidances, describing the quality, safety and efficacy data needed to show similarity between the candidate biosimilar to the reference product. The FDA takes the approach of totality of evidence in assessing that no clinically meaningful differences in safety, purity and potency exist between biosimilar and original product $(10,11)$. In some regions, the approval of copy versions of biologics predates the introduction of biosimilar guidelines (12). Because these cannot be called biosimilars, a myriad of terms has been used such as "intended copies", "non-original biologics" or "non-innovator biologics", "similar biologics" (India), "biogenerics" (Iran) and "biocomparables" (Mexico) (10,13).
Biologics, as opposed to chemically-synthesized small molecule drugs, are extremely intricate and can undergo multiple degradation processes. Thereby, its characterization remains a challenge. The use of living cells may introduce subtle differences despite using the same gene sequence and vector as the innovator. All biologics are subjected to posttranslational modifications, such as deamidation and oxidation, which may affect protein function and result in heterogeneity.

Product-related quality differences may in principle lead to serious adverse events. An often cited incident occurred in 1998 for the cases of Epoetin-associated Pure red cell aplasia (PRCA) in renal failure patients, where the change in the formulation from Human Serum Albumin to polysorbate 80, subcutaneous administration and uncoated robber stoppers have been involved with the presence of anti-drug and neutralizing endogenous erythropoietin antibodies (14). The high prevalence of PRCA in Thailand has been related with the bio-questionable quality of some recombinant human erythropoietin copy products (15). These are clear examples of how subtle changes in manufacturing process and quality properties may have unforeseen clinical consequences.

Currently, seven biosimilar filgrastim products have been approved in the EU (16). One product has successfully entered the US market as the first US biosimilar, Zarzio® (17). Zarzio has proved in US after shown highly similarity in terms of physicochemical properties, biological characterization, pharmacodynamic and pharmacokinetic parameters (18). All demonstrate comparable quality, safety and efficacy to Neupogen $\AA$, as reported in several comparative studies $(1,18-22)$. In less regulated markets, different copies of filgrastim products have also been identified. In Mexico, selected filgrastim biocomparables complied with the pharmacopoeia criteria and showed comparability in terms of quality (23). In India, several copy filgrastim products showed similarity to Neupogen ${ }^{\circledR}$ with respect to physicochemical and biological characteristics $(24,25)$. In Egypt, the quality of one copy filgrastim product was reported to be inferior to that of the innovator product (26). However, there is scarcity of data regarding direct comparison between the biosimilar and copy filgrastim products to the innovator product. The perceptions of clinicians is that copy biologics from less regulated markets are inferior to biosimilars, as these products have not been approved through a stringent regulatory process (27).

Here, we present a head-to-head comparison based on the evaluation of physicochemical properties and in vitro potency of two biosimilars approved in Europe and USA (Zarzio®) and Tevagrastim () and two copy products of filgrastim available in developing countries (Biocilin ${ }^{\circledR}$ and PDgrastim $\AA$ ), using as a reference the innovator product (Neupogen $®)$. To encourage the manufacturers in developing countries to perform a complete analytical and functional head-to-head comparison between the copy product and the innovator, we used selected techniques sensitive, feasible and easy access mainly available in $\mathrm{Ph}$. Eur. 


\section{MATERIALS AND METHODS}

\section{Filgrastim Products}

Table I lists innovator, biosimilar and copy filgrastim products procured from various sources. Different batches of Neupogen were either provided by Sandoz or purchased from the pharmacy at the University Medical Centre Utrecht (UMGU), Utrecht, The Netherlands. Biosimilar filgrastim products, Zarzio and Tevagrastim, were provided by the pharmacy of the UMCU. Copy filgrastim products, Biocilin and PDgrastim, were locally procured from Mexico and Iran, respectively, and shipped to Utrecht University. All products were stored at $2-8^{\circ} \mathrm{C}$ and handled according to the manufacturers' specifications. Expired vials of Neupogen and PDgrastim were analyzed as a worst case scenario for marketed products.

\section{Visual Inspection}

Prior to any measurements, all formulations were visually assessed at the lab bench to check for the presence of visible particulates.

\section{Peptide Mapping}

The primary structural similarities between products were confirmed by peptide mapping in accordance with European Pharmacopeia (Ph. Eur.) monograph for filgrastim concentrated solution (28). Filgrastim chemical reference substances (CRS) with lot number 2, purchased from the European Directorate for the Quality of Medicines and HealthCare (EDQM, Strasbourg, France) and filgrastim samples were pre-concentrated by using Amicon ${ }^{\circledR}$ Ultra- $0.5 \mathrm{ml}$ centrifugal filters with a cut-off of 10,000 NWML (Merck Millipore, Amsterdam, The Netherlands) following the manufacturer's recommendations. In short, $125 \mu \mathrm{g}$ of protein from each sample and standard was loaded to pre-washed filter devices. Retained protein was washed three times with MilliQ water and the concentrated solute was recovered.

Endoproteinase Glu-C from Staphylococcus aureus V8 (Sigma-Aldrich, Zwijndrecht, The Netherlands), which selectively cleaves C-terminal peptide bonds at glutamic acid and aspartic acid residues, was prepared at a protein-to-enzyme ratio of 1:10. Subsequently, $20 \mathrm{mM}$ sodium phosphate buffer $\mathrm{pH} 8.0$ (Sigma-Aldrich) was added to a final volume of $100 \mu \mathrm{l}$ and digestion was carried out at $37^{\circ} \mathrm{C}$ for $17 \mathrm{~h}$. Peptides were separated by using reversed-phase chromatography on a XSelect ${ }^{\circledR} \mathrm{CSH}^{\mathrm{TM}} \mathrm{C} 183.5 \mu \mathrm{m}, 4.6 \times 150$ mm column (Waters Corporation, Milford, Massachusetts, USA) installed in a Waters 2695 Separations Module equipped with a Waters 2487 Dual $\lambda$ Absorbance UV detector set at $215 \mathrm{~nm}$. The column was pre-equilibrated at $60^{\circ} \mathrm{C}$ with $97 \% \mathrm{~A}(0.05 \%$ TFA in 5\% ACN in Milli-Q water) and $3 \% \mathrm{~B}(0.05 \% \mathrm{TFA}$ in $95 \% \mathrm{ACN}$ in Milli-Q water $)$ for minimally $2 \mathrm{~h}$. Separation was achieved by applying the following linear gradients at a flow rate of $0.2 \mathrm{ml} / \mathrm{min}$ : $3 \% \mathrm{~B} \rightarrow 6 \% \mathrm{~B}(0-8 \mathrm{~min}), 6 \% \mathrm{~B} \rightarrow 34 \% \mathrm{~B}(8-25 \mathrm{~min})$, $34 \% \mathrm{~B} \rightarrow 90 \% \mathrm{~B}(25-40 \mathrm{~min}), 90 \% \mathrm{~B}(40-45 \mathrm{~min}), 90 \% \mathrm{~B} \rightarrow$ 3\%B (45-46 min), 3\%B (46-75 min). Zarzio was not included due to lack of sample.

Table I List of Tested Filgrastim Products

\begin{tabular}{|c|c|c|c|c|c|}
\hline Trade name (company) & Lot. no. & Declared potency & Declared content & Excipients & Presentation \\
\hline \multicolumn{6}{|l|}{ Analyzed within shelf life } \\
\hline Neupogen $®$ (Amgen) & |042036A |05668 | & $\begin{array}{l}30 \mathrm{MU} / 0.5 \mathrm{ml} \\
48 \mathrm{MU} / 0.5 \mathrm{ml}\end{array}$ & $\begin{array}{l}300 \mu \mathrm{g} / 0.5 \mathrm{ml} \\
480 \mu \mathrm{g} / 0.5 \mathrm{ml}\end{array}$ & Acetate, sorbitol, polysorbate 80 (PS80) & PFS \\
\hline Zarzio ${ }^{\circledR}$ (Sandoz) & 46081101 & $30 \mathrm{MU} / 0.5 \mathrm{ml}$ & $300 \mu \mathrm{g} / 0.5 \mathrm{ml}$ & Glutamate, sorbitol, PS80 & Vial \\
\hline Tevagrastim $®$ (Teva Pharma) & FL5028G & $30 \mathrm{MU} / 0.5 \mathrm{ml}$ & $300 \mu \mathrm{g} / 0.5 \mathrm{ml}$ & Glacial acetic acid, sorbitol, PS80 & PFS \\
\hline Biocilin ${ }^{\circledR}$ (Dong-A-Pharmaceutical) & 40168 & Not declared & $300 \mu \mathrm{g} / \mathrm{l} .2 \mathrm{ml}$ & Not stated & Vial \\
\hline \multicolumn{6}{|l|}{ Analyzed past the expiry date } \\
\hline Neupogen $®$ (Amgen) & $\begin{array}{l}1025277 \\
|02636| \\
1026690 \\
1026689 \\
102799 \mid \\
\mid 028686 \\
1028687\end{array}$ & $\begin{array}{l}\text { (A) } 48 \mathrm{MU} / 1.6 \mathrm{ml} \\
\text { (B) } 48 \mathrm{MU} / 1.6 \mathrm{ml} \\
\text { (C) } 48 \mathrm{MU} / 1.6 \mathrm{ml} \\
\text { (D) } 48 \mathrm{MU} / 1.6 \mathrm{ml} \\
\text { (E) } 48 \mathrm{MU} / 1.6 \mathrm{ml} \\
\text { (F) } 48 \mathrm{MU} / 1.6 \mathrm{ml} \\
\text { (G) } 48 \mathrm{MU} / 1.6 \mathrm{ml}\end{array}$ & $\begin{array}{l}480 \mu \mathrm{g} / \mathrm{l} .6 \mathrm{ml} \\
480 \mu \mathrm{g} / \mathrm{l} .6 \mathrm{ml} \\
480 \mu \mathrm{g} / \mathrm{l} .6 \mathrm{ml} \\
480 \mu \mathrm{g} / \mathrm{l} .6 \mathrm{ml} \\
480 \mu \mathrm{g} / 1.6 \mathrm{ml} \\
480 \mu \mathrm{g} / \mathrm{l} .6 \mathrm{ml} \\
480 \mu \mathrm{g} / \mathrm{l} .6 \mathrm{ml}\end{array}$ & Acetate, sorbitol, PS80 & $\begin{array}{l}\text { Vial } \\
\text { Vial } \\
\text { Vial } \\
\text { Vial } \\
\text { Vial } \\
\text { Vial } \\
\text { Vial }\end{array}$ \\
\hline PDgrastim ${ }^{\circledR}$ (PooyeshDarou) & $900-34$ & $30 \mathrm{MU} / \mathrm{l} .0 \mathrm{ml}$ & $300 \mu \mathrm{g} / \mathrm{l} .0 \mathrm{ml}$ & Not stated & Vial \\
\hline
\end{tabular}

Different batches of Neupogen are represented by alphabet (A) to $(G)$

PFS: pre-filled syringe 


\section{Circular Dichroism (CD) Spectroscopy}

Circular Dichroism (CD) spectra were acquired with an Olis ${ }^{\circledR}$ Rapid-Scanning Monochromator 1000 (On-Line Instrument System, Bogart, Georgia, USA). Thermal stability experiments were performed at $25,55^{\circ} \mathrm{C}$, i.e., below the melting point $\left(\sim 60^{\circ} \mathrm{C}\right)$ and $70^{\circ} \mathrm{C}$ on $300 \mu \mathrm{g} / \mathrm{mL}$ filgrastim samples, except Biocilin $(250 \mu \mathrm{g} / \mathrm{ml})$. A $0.1 \mathrm{~cm}$ pathlength SUPRASIL grade quartz cell (Hellma Analytics, Müllheim, Germany) was used to record data between 180 and $260 \mathrm{~nm}$ with a $1 \mathrm{~nm}$ sampling interval and an integration time of $10 \mathrm{~s}$. The baseline spectrum was subtracted from each sample spectrum. As not all excipients of filgrastim products are specified by the manufacturers, Neupogen placebo buffer $(50 \mathrm{mg} / \mathrm{ml}$ sorbitol, $0.04 \mathrm{mg} / \mathrm{ml} \mathrm{PS} 80,0.59 \mathrm{mg} / \mathrm{ml}$ sodium acetate and $0.035 \mathrm{mg} / \mathrm{ml}$ sodium chloride) was used to obtain the baseline spectrum. Zarzio was not included due to lack of sample. Data were expressed as the mean residual molar extinction coefficient $(\Delta \varepsilon)$. All chemicals were purchased from Sigma-Aldrich (Zwijndrecht, The Netherlands).

\section{Fluorescence Spectroscopy}

Fluorescence spectra were obtained with an FP-8300 fluorescence spectrometer (JASCO, IJsselstein, The Netherlands). Tertiary structure and thermal stability of filgrastim were evaluated based on the intrinsic fluorescence, by using a temperature ramp from $25^{\circ} \mathrm{C}$ to $70^{\circ} \mathrm{C}$ with $5^{\circ} \mathrm{C}$ increments. Filgrastim samples were kept at $300 \mu \mathrm{g} / \mathrm{ml}$, except Biocilin $(250 \mu \mathrm{g} / \mathrm{ml})$. A $0.3 \mathrm{~cm}$ pathlength SUPRASIL grade quartz cell (Hellma Analytics, Müllheim, Germany) was used to record the emission spectra between 290 and $450 \mathrm{~nm}$ with a $0.5 \mathrm{~nm}$ sampling interval, an excitation wavelength of $280 \mathrm{~nm}$, emission and excitation bandwidths of $5 \mathrm{~nm}$ and a scan speed of $500 \mathrm{~nm} / \mathrm{min}$. The baseline spectrum was subtracted from each sample spectrum. As not all excipients of filgrastim products are specified by the manufacturers, Neupogen placebo formulation $(50 \mathrm{mg} / \mathrm{ml}$ sorbitol, $0.04 \mathrm{mg} / \mathrm{ml}$ PS 80 , $0.59 \mathrm{mg} / \mathrm{ml}$ sodium acetate, and $0.035 \mathrm{mg} / \mathrm{ml}$ sodium chloride) was used to obtain the baseline spectrum. Zarzio was not included due to lack of sample. Data were expressed as fluorescence intensity in function of temperature. All chemicals were purchased from Sigma-Aldrich (Zwijndrecht, The Netherlands).

\section{Sodium Dodecyl Sulfate Polyacrylamide Gel Electrophoresis (SDS-PAGE)}

SDS-PAGE was performed under non-reducing and reducing conditions by using Bolt ${ }^{\circledR} 4-12 \%$ BisTris Plus Gels (10 wells), installed on a Bolt ${ }^{\circledR}$ Mini Gel Tank. Prior to loading, filgrastim samples were mixed with $1 \times$ Bolt ${ }^{\circledR}$ LDS Sample Buffer and heated for $5 \mathrm{~min}$ at $95^{\circ} \mathrm{C}$. On each well, $50 \mathrm{ng}$ of protein was loaded. Under reducing condition, $1 \times$ Bolt ${ }^{\circledR}$ Sample Reducing Agent was added. PageRuler Plus Prestained Protein Ladder, 10-250 kDa, was used as a molecular weight marker. Filgrastim CRS (EDQM) was used as a control. The running condition was set to a constant voltage of $165 \mathrm{~V}$ for 45 min in $1 \times$ Bolt ${ }^{\circledR}$ MOPS SDS running buffer. Proteins were visualized by using a SilverQuest ${ }^{\mathrm{TM}}$ Silver Staining Kit according to the manufacturer's specifications. All materials were ordered from Thermo Scientific (Landsmeer, The Netherlands).

\section{High Performance Size-Exclusion Chromatography (HP-SEC)}

Following the $\mathrm{Ph}$. Eur. monograph for filgrastim concentrated solution (28), HP-SEG was performed on a $5 \mu \mathrm{m}, 300 \times$

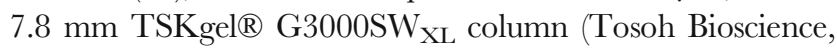
Griesheim, Germany) with a SecurityGuard Universal Guard Cartridge System as a precolumn (Phenomenex ${ }^{\circledR}$, Utrecht, The Netherlands). Both pre-column and column were installed in a Waters 2695 Separations Module (Waters Corporation, Milford, Massachusetts, USA) equipped with Waters 2487 Dual $\lambda$ Absorbance UV and Waters 2475 Multi $\lambda$ fluorescence detectors. UV detection was performed at $215 \mathrm{~nm}$ and $280 \mathrm{~nm}$. For fluorescence detection, excitation was performed at $280 \mathrm{~nm}$, and the emission was recorded at $340 \mathrm{~nm}$. A mobile phase containing $50 \mathrm{mM}$ ammonium hydrogen carbonate (Sigma-Aldrich), adjusted with phosphoric acid (Acros Organics, Geel, Belgium) to $\mathrm{pH}$ 7.0, and filtered through a $0.45 \mu \mathrm{m}$ nylon filter (Sartorius Stedim, Göttingen, Germany), was used. Prior to injection in triplicate, all filgrastim products were diluted to a concentration $0.25 \mathrm{mg} / \mathrm{ml}$ in $100 \mathrm{mM}$ sodium acetate, adjusted with acetic acid (Merck, Darmstadt, Germany) to $\mathrm{pH}$ 5.0. Isocratic separation took place at a flow rate of $0.5 \mathrm{ml} / \mathrm{min}$ for $30 \mathrm{~min}$. At the beginning of each experiment, $50 \mu \mathrm{l}$ of $1 \mathrm{mg} / \mathrm{ml}$ bovine serum albumin (SigmaAldrich) in dilution buffer was injected into the column to reduce non-specific adsorption. The temperature of sample and column was maintained at $20^{\circ} \mathrm{C}$ and $30^{\circ} \mathrm{C}$, respectively. A calibration curve based on monomer peak area was constructed by using seven concentrations of filgrastim CRS in the range of $0.05-1 \mathrm{mg} / \mathrm{ml}$ and used to calculate the concentration of filgrastim monomer in all products. Analysis was performed with Empower 3 software version 7.21.00.00.

\section{Reversed Phase Ultra-Performance Liquid Chromatography (RP-UPLC)}

Oxidized forms of filgrastim, to be used as standards for RPUPLC, were obtained according to the Ph. Eur. monograph for filgrastim concentrated solution (28). Briefly, an aliquot of $100 \mu \mathrm{l}$ of $0.5 \mathrm{mg} / \mathrm{ml}$ filgrastim CRS was treated with $3 \mu \mathrm{l}$ of $30 \%$ hydrogen peroxide (Merck) and incubated at $25^{\circ} \mathrm{C}$ for $15 \mathrm{~min}$ before adding $0.8 \mathrm{mg}$ of L-methionine (Sigma- 
Aldrich). Reduced forms were produced by adding $0.125 \mathrm{mg}$ dithiothreitol to $100 \mu \mathrm{l}$ of $0.5 \mathrm{mg} / \mathrm{ml}$ filgrastim CRS and incubated at $35^{\circ} \mathrm{C}$ for $60 \mathrm{~min}$.

RP-UPLC was performed on an Acquity Ultra Performance LC system (Waters Corporation) where a UPLC Acquity BEH300 C4 column $(1.7 \mu \mathrm{m}, 2.1 \times 50 \mathrm{~mm})$ was installed. The column was equilibrated at $60^{\circ} \mathrm{C}$ with $85 \%$ mobile phase A $(0.1 \%$ trifluoroacetic acid [TFA, Sigma-Aldrich] in Milli-Q water $) / 15 \%$ mobile phase B $(0.1 \%$ TFA in $90 \%$ HPLC grade acetonitrile [Biosolve, Valkenswaard, The Netherlands]) until a stable baseline was reached. Separation was achieved by applying the following linear gradients at a flow rate of $0.25 \mathrm{ml} / \mathrm{min}$ : $15 \%$ B (0-0.5 min), 15\% B-75\% B (0.5-10.5 min), 75\% B- $15 \%$ $\mathrm{B}(10.5-11 \mathrm{~min})$ and $15 \% \mathrm{~B}$ (11-11.5 min). While being maintained at $20^{\circ} \mathrm{C}, 1.5 \mu \mathrm{g}$ of each filgrastim product was injected in triplicate. Detection took place with an Acquity ${ }^{\text {TM }}$ PDA detector (Waters Corporation) at $215 \mathrm{~nm}$.

\section{Endotoxin Test}

Endotoxin concentration in filgrastim products was quantified with an endpoint chromogenic Limulus amebocyte lysate (LAL) QCL1000 TM assay, as described by the manufacturer (Lonza, Basel, Switzerland). Briefly, each filgrastim product was diluted in LAL reagent water at ratio 1:10, 1:20 and 1:40. $25 \mu \mathrm{l}$ of each dilution was transferred to each well of prewarmed LAL reagent grade multiwell plate at $37^{\circ} \mathrm{C}$ in duplicate. Hereafter, an equal volume of LAL was added to each microplate well, followed by gently tapping on the side to facilitate mixing, and the mixture was incubated at $37^{\circ} \mathrm{C}$ for another $10 \mathrm{~min} .50 \mu \mathrm{l}$ of chromogenic substrate was then dispensed to each well. The reaction was stopped after $6 \mathrm{~min}$ by adding $50 \mu \mathrm{l}$ of $25 \%$ (v/v) acetic acid (SigmaAldrich). Absorbance was read at $405 \mathrm{~nm}$ by a SPECTROstar ${ }^{\text {Nano }}$ (BMG Labtech, Ortenberg, Germany) plate reader. A calibration curve was included by preparing dilution series of $E$. coli 0111:B4 endotoxin (0.01-1 EU/ml). Eventually, the endotoxin concentration of filgrastim products was determined from their absorbance by linear regression. Additionally, to verify the lack of product inhibition, dilutions of filgrastim products were spiked with a known amount of endotoxin, i.e., 0.4 endotoxin units $(\mathrm{EU}) / \mathrm{ml}$. All reagents and materials used were purchased at Lonza and were endotoxin free grade-certified, unless indicated otherwise.

\section{Flow Imaging Microscopy}

The analysis of subvisible particles was performed by flow imaging microscopy on a Micro-Flow Imaging (MFI) instrument (MFI5200, Protein Simple, California, USA) equipped with a silane-coated $100-\mu \mathrm{m}$ flow cell. The MFI instrument was operated at high magnification $(14 \times)$ and controlled by using the MFI View System Software (MVSS) version 3.1. Between each measurement, the MFI system was flushed with
$2 \mathrm{ml}$ Milli-Qwater at a flow rate of $0.7 \mathrm{ml} / \mathrm{min}$ and checked for a clean background. Prior to evaluating each sample, buffer components of Neupogen filtered through a $0.2-\mu \mathrm{m}$ filter (Sartorius Stedim) was used to perform "optimize illumination" at a flow rate of $4 \mathrm{ml} / \mathrm{min}$. Due to limited volume, a few products were analyzed only once at a sample volume of $500 \mu$ l. Data analysis was performed in MFI View Analysis Suite version 1.4. To discriminate silicone oil droplet-like particles from protein-like particles and to exclude the air bubbles from analysis, we applied filters, such as Aspect Ratio set as $\geq 0.87$ and Intensity Min $\geq 20$; particles with Aspect Ratio < 0.87 and Intensity $\mathrm{Min} \geq 20$ were considered protein-like particles (29). All chemicals were purchased from SigmaAldrich.

\section{In Vitro Potency Assay}

An in vitro potency assay was performed based on the proliferation of M-NFS-60 cells induced by G-CSF, as described in the $\mathrm{Ph}$. Eur. monograph for filgrastim concentrated solution (28). In short, all filgrastim products and the World Health Organization (WHO) 2nd International Standard (IS) for human GCSF (NIBSC, Hertfordshire, UK) were prepared in assay medium (RPMI 1640 supplemented with L-glutamine, sodium bicarbonate, 10\% fetal bovine serum, $10 \mathrm{mM}$ HEPES buffer and $0.05 \mathrm{mM} 2$ mercaptoethanol) at a starting concentration of $20 \mathrm{ng} / \mathrm{ml}$ and were added to a well of a 96-well microtiter plate (Greiner Bio-One, Alphen a/d Rijn, The Netherlands) in triplicate. A series of 17 threefold dilutions was subsequently prepared to obtain a standard curve. M-NFS-60 cells were harvested and washed twice in assay medium. Hereafter, $\sim 20,000$ cells were added to each well.

After being incubated for $44-48 \mathrm{~h}$ at $37^{\circ} \mathrm{C}$ with $5 \%$ $\mathrm{CO}_{2}$, the cell proliferation was quantified. CellTiter $96 \AA$ AQueous One Solution Cell Proliferation Assay solution (Promega, Leiden, The Netherlands) was added to the cells and the plate was re-incubated for $4 \mathrm{~h}$. The quantity of formazan produced was estimated by recording the absorbance at $490 \mathrm{~nm}$ and $650 \mathrm{~nm}$ (reference wavelength) with a SPECTROstar Nano microplate reader (BMG Labtech, Ortenberg, Germany). In vitro potency was calculated based on WHO 2nd IS with an assigned value for G-CSF activity of 95,000 IU/ampoule using the parallel line assay in Combistats software version 5.0 (EDQM) (30).

\section{RESULTS}

Prior to characterization, all filgrastim products were examined visually. All products were clear and colorless solutions and contained no visible particulates. 


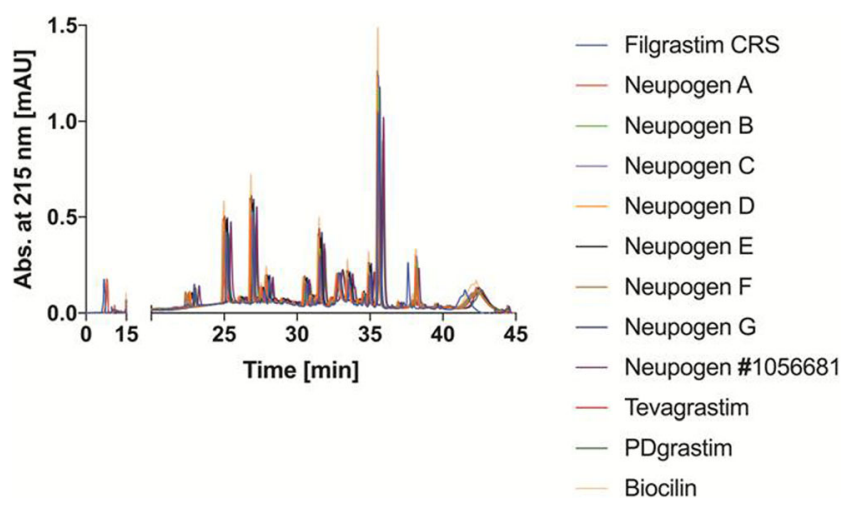

Fig. I Overlay of RP-HPLC chromatograms of endoproteinase Glu-C digested of Filgrastim CRS, Neupogen batch 105668I, Tevagrastim, copy products and several batches of Neupogen.

\section{Structural Analysis of Filgrastim Products}

RP-HPLC chromatograms of a Glu-C peptide map from innovator as well as selected biosimilar and copy filgrastim products are shown in Fig. 1. No differences in amino acid sequence and disulfide-bond formation were identified.

The secondary and tertiary structure of selected filgrastim products were evaluated in function of their thermal stability by circular dichroism and intrinsic fluorescence spectroscopy, respectively.

Fig. 2 shows the far-UV CD spectra of filgrastim products obtained at $25^{\circ} \mathrm{C}$ and $55^{\circ} \mathrm{C}$. All products showed a positive band at $193 \mathrm{~nm}$ and negative bands at $208 \mathrm{~nm}$ and $222 \mathrm{~nm}$ (31), indicating they all share an alpha-helix-rich structure which has been described for filgrastim. (32-34).

Our results are consistent with those reported for other filgrastim formulations available in India (24) and Australia (35). Due to scarce information about the excipient concentrations, the differences in amplitude in the band around $193 \mathrm{~nm}$ could be related to the use of only one background for all samples. Except for PDgrastim, all products displayed similar thermal stability (Fig. 2b).

Protein aggregation represents a main challenge for biopharmaceuticals, where temperature could be a factor. To assess differences in protein conformation and thermal stability between the filgrastim products, a melting curve was monitored from $25^{\circ} \mathrm{C}$ to $70^{\circ} \mathrm{C}$ by the $\mathrm{CD}$ signal at $222 \mathrm{~nm}$ and intrinsic (tryptophan and tyrosine) fluorescence intensity (Fig. 3). The filgrastim products were analyzed at low $\mathrm{pH}$ and the temperature of unfolding was similar in all products between 55 and $60^{\circ} \mathrm{C}$. These results are in agreement with the $\mathrm{T}_{\mathrm{m}}$ previously reported $(33,34,36)$ and consistent with those reported for other filgrastim formulations $(24,35)$. PDgrastim (pink line) showed the lowest thermal stability with a drastic change in conformation at $55^{\circ} \mathrm{C}$. It is clearly different from Neupogen (red line) and the expired batches of Neupogen (black line), and consistent with the CD spectrum showing a loss of the alpha-helix structure (Fig. 2, panel b, pink line).

\section{Characterization of Impurities by SDS-PAGE and HP-SEC}

The identity and purity of different filgrastim products were assessed by SDS-PAGE and HP-SEC. Fig. 4 exhibits silver stained SDS-PAGE gels of all products with a principal band in the range of $15-25 \mathrm{kDa}$ under both non-reducing and reducing conditions. As is the case with the control (image not shown), this band corresponds to the monomeric filgrastim with a theoretical molecular weight of $18.8 \mathrm{kDa}$ (19). No other bands at higher or lower molecular weight than filgrastim monomer were detected in any of the products, including the expired ones. Faint bands identified in some lanes at between 10 and $15 \mathrm{kDa}$ were likely due to overloading of pre-stained protein marker.
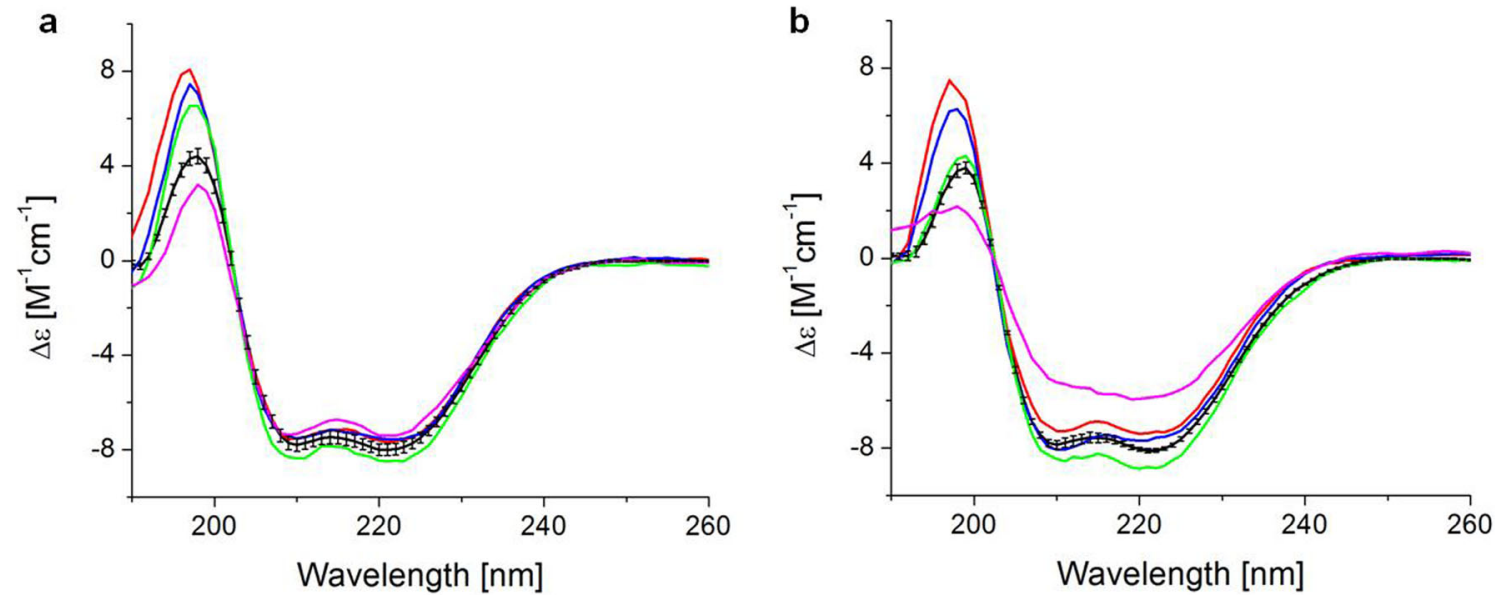

Fig. 2 Circular dichroism spectra of filgrastim products at (a) 25 and (b) $55^{\circ} \mathrm{C}$. Average curve represents the spectra of the expired bathes of Neupogen (black line), Neupogen batch I05668I (red line), Tevagrastim (blue line), Biocilin (green line) and PDgrastim (pink line). 
a

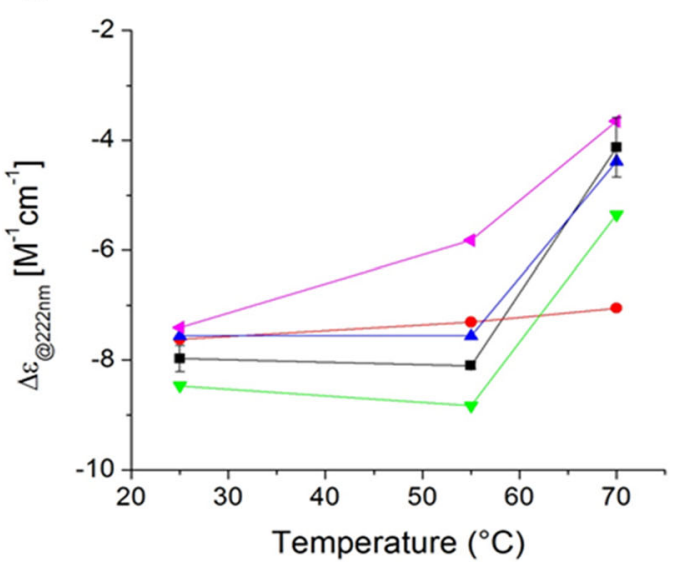

b

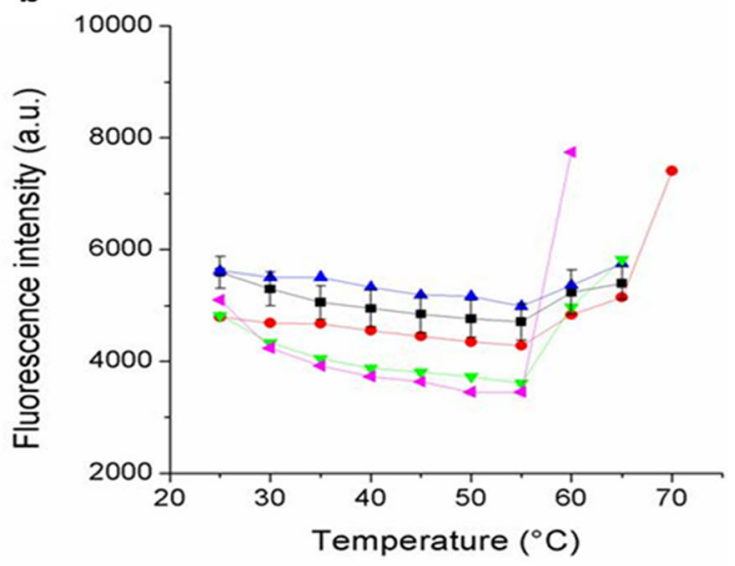

Fig. 3 Thermal stability of selected filgrastim products monitored by (a) circular dichroism at $222 \mathrm{~nm}$ and (b) intrinsic fluorescence from 25 to $70^{\circ} \mathrm{C}$. Average curves represent the results for expired batches of Neupogen (black line), Neupogen batch I05668I (red line), Tevagrastim (blue line), Biocilin (green line) and PDgrastim (pink line).

Similarly, HP-SEC revealed no impurities, i.e., aggregates and fragments, in nearly all products including the expired batches of Neupogen (Fig. 5). For all samples the filgrastim monomer peak eluted at $19.3 \mathrm{~min}$, similar to the retention time of filgrastim stated in the $\mathrm{Ph}$. Eur. monograph for filgrastim concentrated solution (28). The peak eluting at $23 \mathrm{~min}$ is derived from components of the dilution buffer.

In the case of expired products, only in PDgrastim (inset Fig. 5), we detected filgrastim dimer (eluting at $16.9 \mathrm{~min}$ ) and oligomer (eluting at $16.0 \mathrm{~min}$ ) based on relative retention with reference to the filgrastim monomer stated in the Ph. Eur. monograph for filgrastim concentrated solution (28). The relative peak area representing dimer and oligomer compared to the total area of all protein peaks in the chromatograms was found to be $\sim 3.6 \%$ and $\sim 0.1 \%$, respectively. The relative peak area of dimer was found to be higher than the limit of $2 \%$ stated in the $\mathrm{Ph}$. Eur. monograph for filgrastim concentrated solution (28).

As summarized in Table II, we used HP-SEC to measure the monomer content of all filgrastim products based on a calibration curve with filgrastim CRS where the monomer
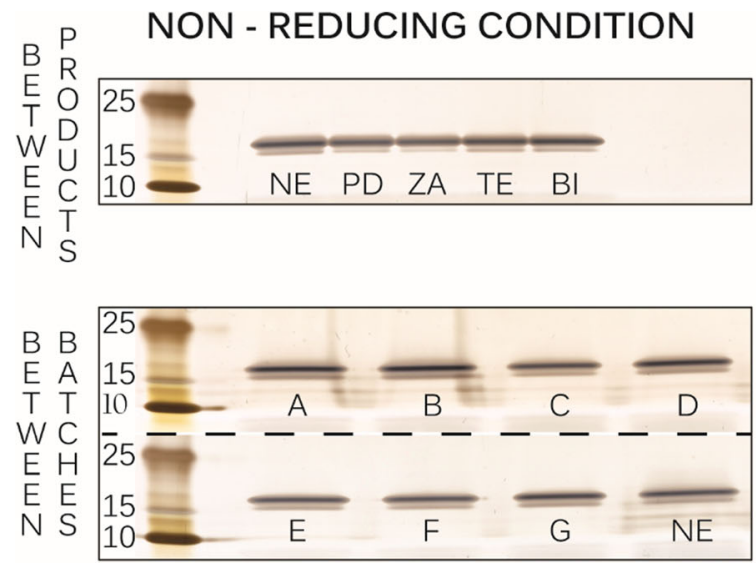

peak areas were plotted against the concentration of filgrastim CRS. Linearity was observed in a concentration range from 0.05 to $1 \mathrm{mg} / \mathrm{ml}\left(\mathrm{R}^{2}=0.9975\right)$. Both Tevagrastim and Zarzio showed a filgrastim monomer content comparable to that of Neupogen. In contrast, the monomer content of Biocilin and PDgrastim were more than twofold lower than that of Neupogen. Moreover, the expired batches of Neupogen showed a substantially reduced monomer content. Additionally, the ratio between the total peak areas of filgrastim monomer detected by fluorescence and UV detectors was a bit lower for PDgrastim as compared to all other products. This may point to a difference in protein structure and aggregation as shown by HP-SEC, although we cannot exclude that PDgrastim has shown different stability by fluorescence spectroscopy than the rest of the products.

\section{Identification of Related Proteins of Filgrastim}

The oxidation of methionine residues to methionine sulfoxide or methionine sulfone is one of the degradation pathways

\section{REDUCING CONDITION}
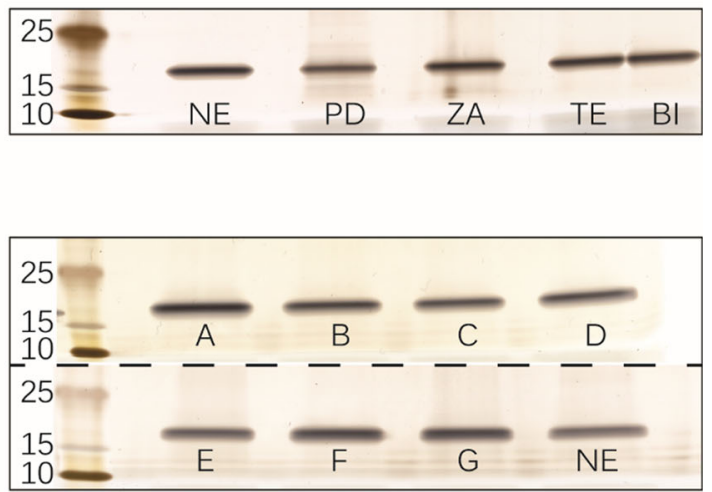

Fig. 4 Filgrastim products on 4-12\% Bolt $®$ BisTris gel visualized by silver staining. Neupogen (NE) batch I042036A, PDgrastim (PD), Zarzio (ZA), Tevagrastim (TE) and Biocilin (BI) as well as additional batches of Neupogen (A-G). 


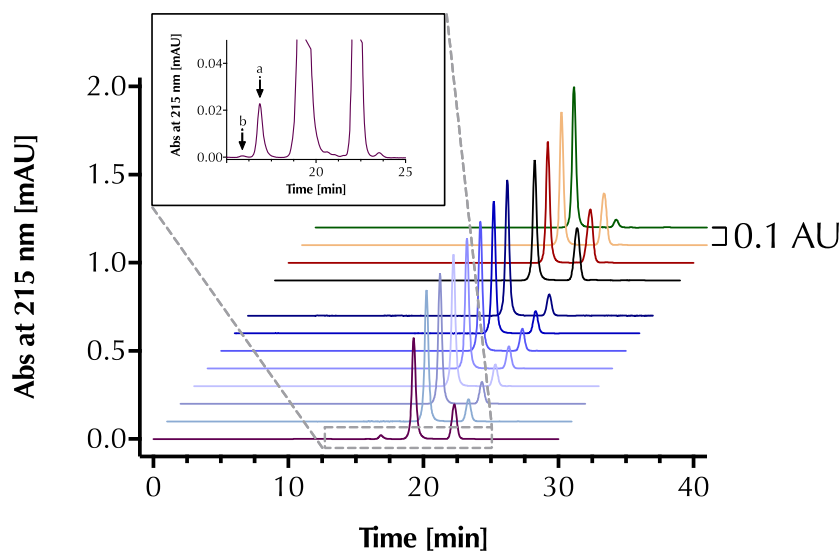

Fig. 5 HPSEC chromatograms of (top to bottom) Biocilin (green), Tevagrastim (pink), Zarzio (brown), and Neupogen batch I042036A (black) followed by seven batches of expired Neupogen (several shades of blue) and PDgrastim (purple). The inset is the zoom of PDgrastim's chromatogram. Peak (a) is filgrastim dimer and peak (b) is filgrastim oligomer.

present in biopharmaceuticals during formulation and storage. Common antioxidants used are glutathione, acetylcysteine, methionine, ascorbic acid and sodium bisulfite (37). However, filgrastim formulations do not contain an antioxidant (24), maybe due to low oxidation rate of Met1, Met122, Met127, Met138 at low pH (37).

Possible product-related impurities, such as oxidized and reduced variants, contained in filgrastim products were analyzed by RP-UPLC. As in the case with filgrastim CRS, all products showed a main filgrastim peak, which eluted at $\sim 6.2 \mathrm{~min}$ (Fig. 6). Filgrastim CRS and all products showed oxidized variants, which eluted between $5.5 \mathrm{~min}$ and $6.0 \mathrm{~min}$ and deamidated variants eluted between 6.3 and $6.5 \mathrm{~min}$ (Fig. 6a). While PDgrastim contained distinct oxidized variant at $5.8 \mathrm{~min}$, Biocilin contained another deamidated variant at $6.4 \mathrm{~min}$ (Fig. 6b). The total area percentage of either oxidized or deamidated variants was calculated for each filgrastim product and compared to the total peak area of all peaks in the chromatogram. The relative peak area of either oxidized or deamidated variants for Zarzio and Tevagrastim was below the limits stated on Ph. Eur. (28) and were comparable to those of Neupogen. While the relative peak area of the impurity in Biocilin was below the limits, PDgrastim contained a relative peak area of oxidized variants $\sim 2.1 \%$ above the acceptable limit.

Oxidation is a common degradation pathway, often resulting in structural changes (38) and might become the shelf-life limiting factor (39). PDgrastim shows the highest level of oxidation, aggregation and loss of second and tertiary structures, maybe due to a difference in excipients. Expired batches of Neupogen showed comparable low relative peak areas of oxidized and deamidated variants as the non-expired batch (Fig. 6c).

Table II Comparison of Monomer Content and Potency of Tested Filgrastim Products

\begin{tabular}{|c|c|c|c|c|c|}
\hline Trade Name & & $\begin{array}{l}\text { Monomer content HPSEC, } \\
U V_{215} \mathrm{~nm}[\mathrm{mg} / \mathrm{ml}] \pm \mathrm{SD}\end{array}$ & $\begin{array}{l}\text { In vitro potency } \\
\text { [Lower-Upper limit] }\end{array}$ & $\begin{array}{l}\text { Total AUC fluorescence / } \\
\text { total AUC UV } 280 \mathrm{~nm} \\
\text { from HP-SEC } \pm \mathrm{SD}\end{array}$ & Specific activity \\
\hline Neupogen & & $0.647 \pm 0.022$ & $\begin{array}{l}24.1 \mathrm{MU} / 0.5 \mathrm{ml} \\
{[23.1-25.1]}\end{array}$ & $719.2 \pm 6.6$ & $74.4 \mathrm{MU} / \mathrm{mg}$ \\
\hline Zarzio & & $0.650 \pm 0.028$ & $\begin{array}{l}30.3 \mathrm{MU} / 0.5 \mathrm{ml} \\
{[29.1-31.6]}\end{array}$ & $737.6 \pm 5.1$ & $93.2 \mathrm{MU} / \mathrm{mg}$ \\
\hline Tevagrastim & & $0.691 \pm 0.027$ & $\begin{array}{l}31.1 \mathrm{MU} / 1.0 \mathrm{ml} \\
{[29.8-32.4]}\end{array}$ & $735.4 \pm 6.9$ & $89.9 \mathrm{MU} / \mathrm{mg}$ \\
\hline Biocilin & & $0.317 \pm 0.016$ & $\begin{array}{l}23.1 \mathrm{MU} / \mathrm{I} .2 \mathrm{ml} \\
{[22.2-24.1]}\end{array}$ & $732.4 \pm 22.9$ & $60.7 \mathrm{MU} / \mathrm{mg}$ \\
\hline \multirow[t]{7}{*}{ Neupogen } & A & $0.360 \pm 0.017$ & $\begin{array}{l}40.5 \mathrm{MU} / \mathrm{l} .6 \mathrm{ml} \\
{[38.9-42.2]}\end{array}$ & $730.9 \pm 27.0$ & 70.3 MU/mg \\
\hline & B & $0.353 \pm 0.016$ & $\begin{array}{l}39.8 \mathrm{MU} / \mathrm{l} .6 \mathrm{ml} \\
{[38.2-41.5]}\end{array}$ & $741.6 \pm 8.0$ & $70.4 \mathrm{MU} / \mathrm{mg}$ \\
\hline & C & $0.358 \pm 0.016$ & $\begin{array}{l}41.6 \mathrm{MU} / \mathrm{l} .6 \mathrm{ml} \\
{[39.9-43.3]}\end{array}$ & $747.0 \pm 21.8$ & $72.6 \mathrm{MU} / \mathrm{mg}$ \\
\hline & $\mathrm{D}$ & $0.354 \pm 0.016$ & $\begin{array}{l}42.1 \mathrm{MU} / \mathrm{l} .6 \mathrm{ml} \\
{[40.4-43.8]}\end{array}$ & $737.4 \pm 27.2$ & $74.3 \mathrm{MU} / \mathrm{mg}$ \\
\hline & $E$ & $0.353 \pm 0.017$ & $\begin{array}{l}41.1 \mathrm{MU} / \mathrm{l} .6 \mathrm{ml} \\
{[39.4-42.8]}\end{array}$ & $737.3 \pm 11.1$ & $72.7 \mathrm{MU} / \mathrm{mg}$ \\
\hline & $F$ & $0.359 \pm 0.016$ & $\begin{array}{l}39.3 \mathrm{MU} / \mathrm{l} .6 \mathrm{ml} \\
{[37.7-40.9]}\end{array}$ & $738.1 \pm 11.4$ & $68.4 \mathrm{MU} / \mathrm{mg}$ \\
\hline & G & $0.368 \pm 0.015$ & $\begin{array}{l}41.9 \mathrm{MU} / 1.6 \mathrm{ml} \\
{[40.2-43.7]}\end{array}$ & $729.4 \pm 17.0$ & $71.2 \mathrm{MU} / \mathrm{mg}$ \\
\hline PDgrastim & & $0.258 \pm 0.007$ & $\begin{array}{l}26.4 \mathrm{MU} / 0.5 \mathrm{ml} \\
{[25.4-27.5]}\end{array}$ & $669.1 \pm 27.9$ & $102.4 \mathrm{MU} / \mathrm{mg}$ \\
\hline
\end{tabular}

SD standard deviation 


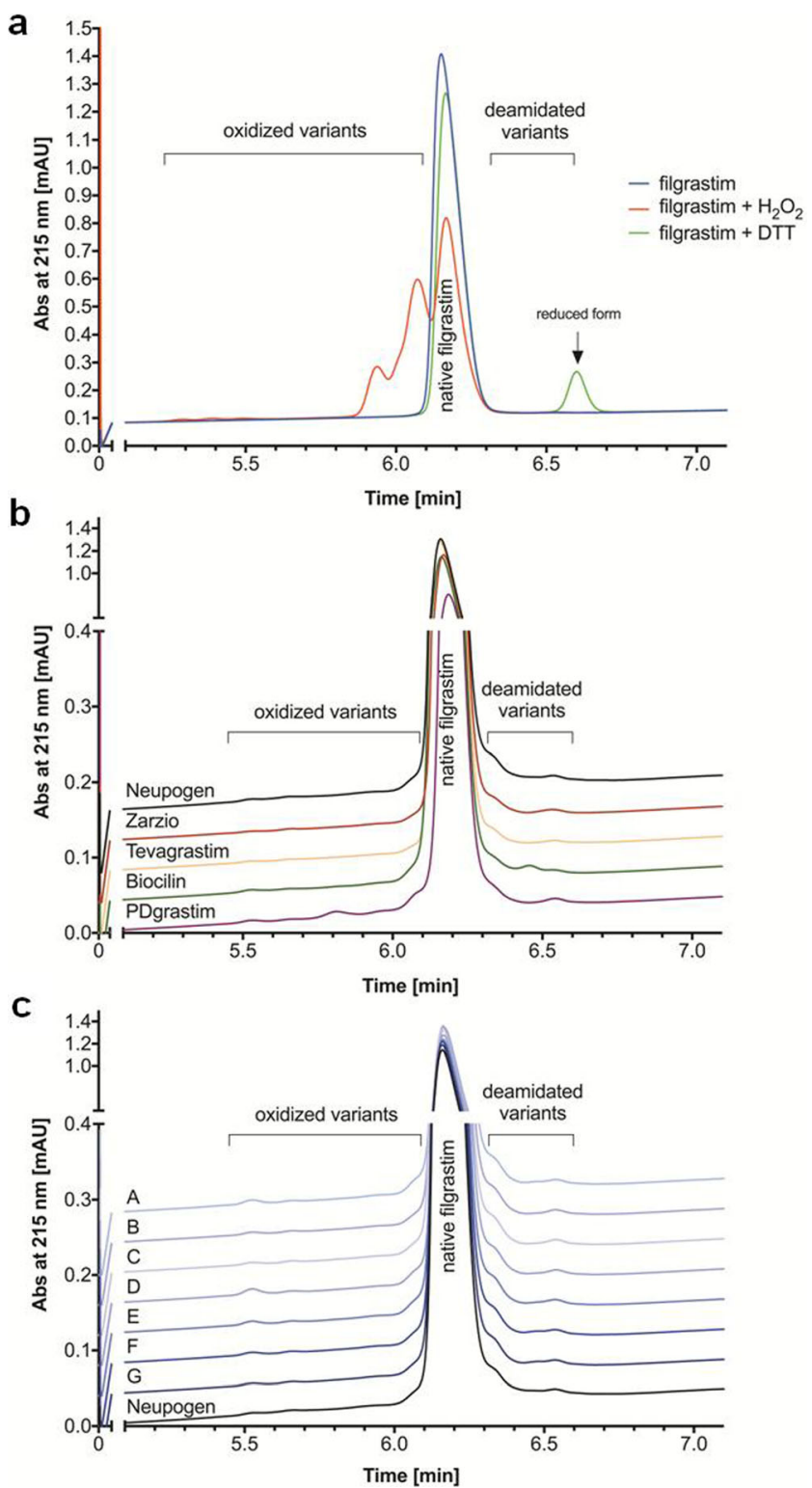

Fig. 6 RP-UPLC chromatograms of (a) filgrastim CRS, (b) biosimilar and copy filgrastim products, and (c) expired batches of Neupogen compared to non-expired Neupogen.

\section{Evaluation of Bacterial Endotoxin in Filgrastim Products}

Endotoxin may be introduced during manufacturing especially in the case of filgrastim as it is expressed in E. coli. Hence, it is critical to quantify endotoxin in drug products because the presence of endotoxin can result in pyrogenic responses and may affect immunogenicity of the finished products $(40,41)$. The endotoxin level of Biosimilars (Zarzio and Tevagrastim) and copy products (Biocilin and PDgrastim) was compared with the innovator (Neupogen batch 1042036A and expired Neupogen A-G). The endotoxin content of all filgrastim products was far below the limit $2 \mathrm{IU} / \mathrm{mg}$ of protein, as stated in the $\mathrm{Ph}$. Eur. monograph on filgrastim concentrated solution (28).

\section{Characterization of Subvisible Particles in Filgrastim Products}

Subvisible particles in the range of $1-100 \mu \mathrm{m}$ were sized and counted by MFI. Silicone oil droplets are distinguished from proteinaceous particles by using the image filtering capabilities of MFI, namely aspect ratio and intensity minimum, as described elsewhere (29). Fig. 7 exhibits representative images of proteinlike and silicone oil droplet-like particles. In contrast to the uniform circularity of the silicone oil droplets, protein-like particles are highly heterogeneous in shape and size. Filgrastim proteinaceous particles ranged from small translucent ovals of $5 \mu \mathrm{m}$ to fiber-like and irregularly shaped particles up to about $40 \mu \mathrm{m}$.

The particle concentrations are listed in Table III. Neupogen and Tevagrastim supplied in PFS had much higher concentrations of protein-like and silicone oil droplet-like particles than the other analyzed products, which are presented in vials. In contrast with the glass vial with rubber stopper, the PFS has multiplex reactive surfaces which may contribute to the formation of particles $(42,43)$. Considering that MFI is more sensitive than light obscuration to detect proteinaceous particles (29), our results suggest that in all cases, the average number of particles present in the analyzed filgrastim products was far below the limit of 6000 particles $\geq 10 \mu \mathrm{m} /$ container and 600 particles $\geq 25 \mu \mathrm{m} /$ container based on light obscuration, as stated in the respective Ph. Eur. monograph (44).

\section{Determination of In Vitro Potency of Filgrastim Products}

The in vitro potency of filgrastim products was measured by comparing its proliferative effect in M-NFS-60 cells with 2nd WHO G-CSF IS. Table II lists the estimated potencies of all products. The in vitro potency of most products was between 80 and $125 \%$ of the declared potency, thereby meeting the specifications of the Ph. Eur. monograph for filgrastim concentrated solution (28). However, for Biocilin this could not be determined because the package or website does not state the potency.

Specific activity was determined based on the outcome of the potency assay and the filgrastim monomer content. We focused on the monomer due to higher in vitro biological activity than filgrastim dimers (45). Whereas Tevagrastim and Zarzio showed a slightly higher specific activity than Neupogen, the specific activity of PDgrastim was substantially higher. In contrast, Biocilin exhibited a lower specific activity than Neupogen. All expired batches of Neupogen had a comparable specific activity as the non-expired batch.

\section{DISCUSSION}

The current study showed that the quality of analyzed filgrastim products approved by the EMA (Zarzio and Tevagrastim) was comparable to that of the innovator product 
Fig. 7 Representative images of protein-like and silicone oil dropletlike particles observed by MFI in selected filgrastim products.

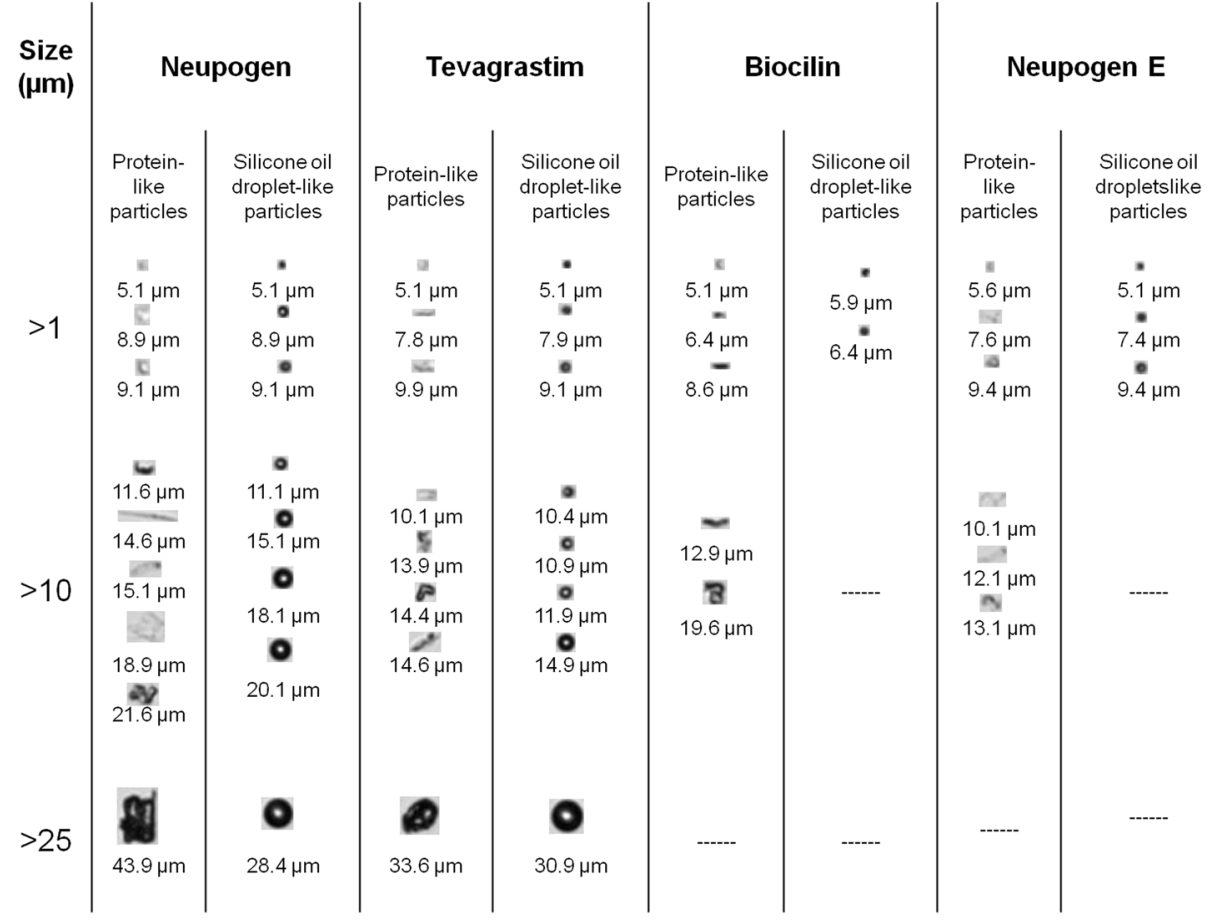

activity are not available in the public domain. In contrast, the physicochemical and biological characterization of Zarzio is available and shows a high similarity in the primary, secondary and tertiary protein structure, mass, size, purity, charge, hydrophobicity and bioactivity to Neupogen (18). However, a recent pharmacovigilance study conducted in Mexico for filgrastim products including Biocilin in cancer patients detected no new adverse events, suggesting that the observed quality differences in Biocilin seem not to have any impact on product safety (47). PDgrastim and several batches of Neupogen were received close to their expiration date. Even so we included them, to gain insight into the quality of expired copy filgrastim product in comparison with expired innovator as a worst case scenario in the market. Although PDgrastim displayed a lower monomer

Table III Comparison of Protein-Like Particles and Silicone Oil Droplet-Like Particle Concentrations (Particles/ml) in Some Filgrastim Products Measured by MFI

\begin{tabular}{|c|c|c|c|c|c|c|c|c|c|c|c|}
\hline \multirow[t]{3}{*}{ Trade name } & & \multicolumn{10}{|c|}{ Size range $[\mu \mathrm{m}]$} \\
\hline & & \multicolumn{5}{|c|}{ Protein-like particles [particles/ml] } & \multicolumn{5}{|c|}{ Silicone oil droplet-like particles [particles/ml] } \\
\hline & & $\geq 1$ & $\geq 2$ & $\geq 5$ & $\geq 10$ & $\geq 25$ & $\geq 1$ & $\geq 2$ & $\geq 5$ & $\geq 10$ & $\geq 25$ \\
\hline \multicolumn{2}{|l|}{ Neupogen } & 60,369 & 18,244 & 764 & 92 & 4 & 17,724 & 25,123 & 4945 & 363 & 11 \\
\hline \multicolumn{2}{|l|}{ Tevagrastim } & 27,439 & 4276 & 237 & 38 & 4 & 6932 & 3638 & 397 & 57 & 4 \\
\hline \multicolumn{2}{|l|}{ Biocilin } & 8021 & 546 & 23 & 8 & 0 & 2182 & 413 & 8 & 0 & 0 \\
\hline \multirow[t]{4}{*}{ Neupogen } & A & 9260 & 944 & 57 & 8 & 4 & 2797 & 1620 & 134 & 4 & 0 \\
\hline & B & I5,557 & 1972 & 164 & 69 & 0 & 6722 & 3183 & 88 & 11 & 0 \\
\hline & E & 19,440 & 1525 & 103 & 27 & 0 & 6168 & 2174 & 118 & 0 & 0 \\
\hline & $\mathrm{F}$ & 20,873 & 1204 & 99 & | | & 8 & 6199 & 1380 & 88 & 19 & 4 \\
\hline
\end{tabular}


content than stated and 2.5-fold lower than Neupogen, it exhibited a substantially higher specific activity compared to Neupogen. This could be due to differences in structure, as demonstrated by HP-SEC. In addition to specific activity, PDgrastim also showed a higher relative content of dimer and oxidized variants, and a lower thermal stability than Neupogen. No differences were observed in any expired batches of Neupogen.

We observed a higher concentration of silicone oil dropletlike particles of $>10$ and $>25 \mu \mathrm{m}$ in products supplied in PFS (Neupogen and Tevagrastim). The pre-filled syringes use silicone oil to lubricate the needle and glass barrel to improve the motion of the plunger $(42,48)$.

We analyzed two copy filgrastim products, but it should be considered that more products are available in less regulated markets. Testing these products will provide more insight into the quality of available copy filgrastim products in general. Additionally, future studies should include more assays and batches to provide more robust comparative quality data. Here, we clearly show that there is not excuse to skip the physicochemical and biological comparison between copy products and innovator by any manufacturer.

\section{CONCLUSION}

Here, we report a head-to-head comparative quality study of biosimilars approved in Europe and US, and copy filgrastim products available in developing countries. Using selected analytical tools and in vitro bioassay, we demonstrate no significant differences in quality between the filgrastim products studied, except for the specific activity of the two copy products of filgrastim. PDgrastim showed presence of impurities and lower thermal stability than the rest of the products. Looking forward manufacturers should put more efforts in making such comparative quality studies.

\section{ACKNOWLEDGMENTS AND DISCLOSURES}

The authors acknowledge Hans Ebbers and Linda McPhee for critical reading of this manuscript and Ahmad S. Sediq for helping with the MFI measurements. This study was partially supported by Sandoz and a fellowship for M.M. by Consejo Nacional de Ciencia y Tecnología (Conacyt). L.A.H., M.M., R.F.M-B., G. C-H., and H.S. declare no conflict of interest. W.J. is a scientific advisor at Coriolis Pharma, Martinsried, Germany.

Open Access This article is distributed under the terms of the Creative Commons Attribution 4.0 International License (http://creativecommons.org/licenses/by/4.0/), which permits unrestricted use, distribution, and reproduction in any medium, provided you give appropriate credit to the original author(s) and the source, provide a link to the Creative Commons license, and indicate if changes were made.

\section{REFERENCES}

1. Barosi G, Bosi A, Abbracchio MP, Danesi R, Genazzani A, Corradini $\mathrm{P}$, et al. Key concepts and critical issues on epoetin and filgrastim biosimilars. A position paper from the Italian Society of Hematology, Italian Society of Experimental Hematology, and Italian Group for Bone Marrow Transplantation. Haematologica. 2011;96(7):937-42.

2. Hoglund M. Glycosylated and non-glycosylated recombinant human granulocyte colony-stimulating factor (rhG-CSF)-what is the difference? Med Oncol. 1998;15(4):229-33.

3. Herman AC, Boone TC, Lu HS. Characterization, formulation, and stability of Neupogen (Filgrastim), a recombinant human granulocyte-colony stimulating factor. Pharma Biotech. 1996;9: 303-28.

4. Molineux G. The design and development of pegfilgrastim (PEGrmetHuG-CSF, Neulasta). Curr Pharm Des. 2004;10(11):1235-44.

5. Wadhwa M, Thorpe R. Haematopoietic growth factors and their therapeutic use. Thromb Haemost. 2008;99(5):863-73.

6. Lyman G DD. Hematopoietic growth factors in oncology: Springer Science \& Business Media; 2010.

7. Hoggatt J, Pelus LM. New G-CSF agonists for neutropenia therapy. Expert Opin Investig Drugs. 2014;23(1):21-35.

8. Khoury HJ, Loberiza FR Jr, Ringden O, Barrett AJ, Bolwell BJ, Cahn JY, et al. Impact of posttransplantation G-CSF on outcomes of allogeneic hematopoietic stem cell transplantation. Blood. 2006;107(4):1712-6.

9. Crommelin DJ, Shah VP, Klebovich I, McNeil SE, Weinstein V, Fluhmann B, et al. The similarity question for biologicals and nonbiological complex drugs. Eur J Pharm Sci. 2015;76:10-7.

10. Desanvicente-Celis ZC-MJ, Enciso-Zuluaga M, Anaya JM. Similar biotherapeutic products in Latin America. Regulation and opportunities for patients with autoimmune diseases. Biosimilars. 2013;3(3):1-17.

11. FDA. Biosimilars.; 2015-2017. Available from: https://www.fda. gov/Drugs/GuidanceComplianceRegulatoryInformation/ Guidances/ucm290967.htm.

12. de Mora F. Biosimilar: what it is not. Br J Clin Pharmacol. 2015;80(5):949-56.

13. GaBI-online. Biosimilars of filgrastim 2015.; Available from: http://www.gabionline.net/Biosimilars/General/Biosimilars-offilgrastim.

14. McKoy JM, Stonecash RE, Cournoyer D, Rossert J, Nissenson AR, Raisch DW, et al. Epoetin-associated pure red cell aplasia: past, present, and future considerations. Transfusion. 2008;48(8):1754-62.

15. Halim LA, Brinks V, Jiskoot W, Romeijn S, Praditpornsilpa K, Assawamakin A, et al. How bio-questionable are the different recombinant human erythropoietin copy products in Thailand? Pharm Res. 2014;31(5):1210-8.

16. Welte K. G-CSF: filgrastim, lenograstim and biosimilars. Expert Opin Biol Ther. 2014;14(7):983-93.

17. Holzmann J, Balser S, Windisch J. Totality of the evidence at work: the first U.S. biosimilar. Expert Opin Biol Ther. 2016;16(2):137-42.

18. Sorgel F, Schwebig A, Holzmann J, Prasch S, Singh P, Kinzig M. Comparability of biosimilar filgrastim with originator filgrastim: protein characterization, pharmacodynamics, and pharmacokinetics. BioDrugs. 2015;29(2):123-31.

19. Skrlin A, Radic I, Vuletic M, Schwinke D, Runac D, Kusalic T, et al. Comparison of the physicochemical properties of a biosimilar 
filgrastim with those of reference filgrastim. Biologicals. 2010;38(5): 557-66.

20. Abraham I, Tharmarajah S, MacDonald K. Clinical safety of biosimilar recombinant human granulocyte colony-stimulating factors. Expert Opin Drug Saf. 2013;12(2):235-46.

21. Gascon P, Tesch H, Verpoort K, Rosati MS, Salesi N, Agrawal S, et al. Clinical experience with Zarzio $(\mathrm{R})$ in Europe: what have we learned? Support Care Cancer. 2013;21(10):2925-32.

22. Sorgel F, Lerch H, Lauber T. Physicochemical and biologic comparability of a biosimilar granulocyte colony-stimulating factor with its reference product. BioDrugs. 2010;24(6):347-57.

23. Mendoza-Macedo K, Romero-Díaz AJ, Miranda-Hernández MP, Campos-García VR, Ramírez-Ibañez ND, Juárez-Bayardo LC, et al. Characterization and comparability of biosimilars: a filgrastim case of study and regulatory perspectives for Latin America. Electron J Biotechnol. 2016;24:63-9.

24. Levy MJ, Gucinski AC, Sommers CD, Ghasriani H, Wang B, Keire DA, et al. Analytical techniques and bioactivity assays to compare the structure and function of filgrastim (granulocyte-colony stimulating factor) therapeutics from different manufacturers. Anal Bioanal Chem. 2014;406(26):6559-67.

25. Nupur N, Singh SK, Narula G, Rathore AS. Assessing analytical comparability of biosimilars: GCSF as a case study. J Chromatogr B Analyt Technol Biomed Life Sci. 2016;1032:165-71.

26. Shaltout EL, Al-Ghobashy MA, Fathalla FA, Salem MY. Chromatographic and electrophoretic assessment of Filgrastim biosimilars in pharmaceutical formulations. J Pharm Biomed Anal. 2014;97:72-80.

27. Roger SD, Goldsmith D. Biosimilars: it's not as simple as cost alone. J Clin Pharm Ther. 2008;33(5):459-64.

28. Pharmacopoeia Eur. Filgrastim Concentrated Solution. Monograph 2206. European Pharmacopoeia Online. 8.8. Strasbourg: Council of Europe: EDQM.; 2016.

29. Sharma DK, King D, Oma P, Merchant C. Micro-flow imaging: flow microscopy applied to sub-visible particulate analysis in protein formulations. AAPS J. 2010;12(3):455-64.

30. Pharmacopoeia Eur. Statistical Analysis of Results of Biological Assays and Tests. Monograph 50300. European Pharmacopoeia Online. 8.8. Strasbourg: Council of Europe: EDQM.; 2016.

31. Greenfield NJ. Using circular dichroism spectra to estimate protein secondary structure. Nat Protoc. 2006;1(6):2876-90.

32. Watson C, Sharp JS. Conformational analysis of therapeutic proteins by hydroxyl radical protein footprinting. AAPS J. 2012;14(2): 206-17.

33. Chi EY, Krishnan S, Kendrick BS, Chang BS, Carpenter JF, Randolph TW. Roles of conformational stability and colloidal stability in the aggregation of recombinant human granulocyte colony-stimulating factor. Protein Sci. 2003;12(5):903-13.

34. Krishnan S, Chi EY, Webb JN, Chang BS, Shan D, Goldenberg $\mathrm{M}$, et al. Aggregation of granulocyte colony stimulating factor under physiological conditions: characterization and thermodynamic inhibition. Biochemistry. 2002;41(20):6422-31.

35. Kempson IM, Chang P, Bremmell K, Prestidge CA. Low temperature thermal dependent Filgrastim adsorption behavior detected with ToF-SIMS. Langmuir. 2013;29(50):15573-8.

36. Robinson MJ, Matejtschuk P, Bristow AF, Dalby PA. Tm-values and unfolded fraction can predict aggregation rates for granulocyte Colony stimulating factor variant formulations but not under predominantly native conditions. Mol Pharm. 2018;15(1):256-67.

37. Yin J, Chu JW, Ricci MS, Brems DN, Wang DI, Trout BL. Effects of antioxidants on the hydrogen peroxide-mediated oxidation of methionine residues in granulocyte colony-stimulating factor and human parathyroid hormone fragment 13-34. Pharm Res. 2004;21(12):2377-83.

38. Pan B, Abel J, Ricci MS, Brems DN, Wang DI, Trout BL. Comparative oxidation studies of methionine residues reflect a structural effect on chemical kinetics in rhG-CSF. Biochemistry. 2006;45(51):15430-43.

39. Holzmann J, Hausberger A, Rupprechter A, Toll H. Top-down MS for rapid methionine oxidation site assignment in filgrastim. Anal Bioanal Chem. 2013;405(21):6667-74.

40. FDA. Pyrogens, Still a Danger; 2015 January 26. Available from: https://www.fda.gov/ICEGI/Inspections/InspectionGuides/ InspectionTechnicalGuides/ucm072906.htm.

41. Heumann D, Roger T. Initial responses to endotoxins and gramnegative bacteria. Clin Chim Acta. 2002;323(1-2):59-72.

42. Bai S, Landsman P, Spencer A, DeCollibus D, Vega F, Temel DB, et al. Evaluation of incremental Siliconization levels on soluble aggregates, submicron and subvisible particles in a prefilled syringe product. J Pharm Sci. 2016;105(1):50-63.

43. Krayukhina E, Tsumoto K, Uchiyama S, Fukui K. Effects of syringe material and silicone oil lubrication on the stability of pharmaceutical proteins. J Pharm Sci. 2015;104(2):527-35.

44. Pharmacopoeia Eur. Particulate Contamination: Sub-Visible Particles. Monograph 20919. European Pharmacopoeia Online. 8.8. Strasbourg: Council of Europe: EDQM.; 2011.

45. Fidler K, Jevsevar S, Milunovic T, Skrajnar S, Premzl A, Kunstelj $\mathrm{M}$, et al. The characterization and potential use of G-CSF dimers and their Pegylated conjugates. Acta Chim Slov. 201 1;58(1):1-8.

46. Lopez SC. Mexico recovers leadership on regulation of biosimilar biotech drugs. Gac Med Mex. 2012;148(1):83-90.

47. Huerta-Sanchez OMA-PJ, Meneses-García A, Herrera-Gómez Á, Herrera-Hernández R, Monroy Cruz MT, Burgeño-Ferreira JA, et al. Implementation of a robust Pharmacovigilance method for Filgrastim non-innovator products in Cancer patients in routine clinical practice complying with Mexican regulations for Biocomparables. Aust J Pharm. 2015;3(4):1-6.

48. Demeule B, Messick S, Shire SJ, Liu J. Characterization of particles in protein solutions: reaching the limits of current technologies. AAPS J. 2010;12(4):708-15. 